ISTIGHNA, Vol. 3, No 2, Juli 2020 P-ISSN 1979-2824 E-ISSN 2655-8459

Homepage: http://e-journal.stit-islamic-village.ac.id/index.php/istighna

Khoirun Nisa, Abdul Muhid

Peran Interaksi Sosial Terhadap Pola Asuh Perkembangan Anak

di Keluaraga Dalam Pandangan Islam

\title{
PERAN INTERAKSI SOSIAL TERHADAP POLA ASUH \\ PERKEMBANGAN ANAK DI KELUARGA DALAM PANDANGAN \\ ISLAM
}

\author{
Khoirun Nisa \\ khoirunnisa31986@gmail.com \\ UIN Sunan Ampel Surabaya \\ Abdul Muhid \\ abdulmuhid@uinsby.ac.id \\ UIN Sunan Ampel Surabaya
}

\begin{abstract}
Family involvement in developing children's abilities and social behavior is very much needed through interaction as a medium of actualization. The role of parents and children will be the basis of influence on child development parenting. in social life a person needs to interact with other people and when interacting one finds the true nature of himself as a social creature who needs each other. The task of parents must continue to hone and educate their children so that they can always socialize and interact well This article aims to discuss how the role of social interaction on parenting child development in the family in Islamic view. because more or less parents ignore it busy with what is being done so there is no word of attention and indifference to children. And in essence, parents are the most important part as a benchmark for children's growth and development.
\end{abstract}

\section{Keywords: Social Interaction; Parenting: Child Development}

Abstrak: Keterlibatan keluraga dalam mengembangkan kemampuan dan perilaku sosial anak sangat dibutuhkan melalui Interaksi sebagai media aktualisasi. Peran orang tua dan anak akan menjadi dasar pengaruh terhadap pola asuh perkembangan anak. di dalam kehidupan bermasyarakat seseorang perlu berinteraksi dengan orang lain dan pada saat berinteraksi tersebut seseorang menemukan hakikat dirinya sebagai makhluk sosial yang saling membutuhkan. Tugas orang tua harus tetap mengasah dan mendidik anaknya agar selalu dapat bersosialisai dan berinteraksi dengan baik Artikel ini bertujuan untuk membahas bagaimana peran interaksi sosial terhadap pola asuh pekembangan anak di keluarga dalam pandangan islam. karena sedikit banyak orang tua mengabaikannya sibuk dengan apa yang sedang dilakukan sehingga tidak ada kata perhatian dan acuh kepada anak. Dan pada intinya orang tua adalah bagian terpenting sebagai patokan atas tumbuh kembang anak.

Kata Kunci: Interaksi Sosial; Pola Asuh;Perkembangan Anak

Peer reviewed under reponsibility of STIT ISLAMIC VILLAGE.

(C) 2018 STIT ISLAMIC VILLAGE, All right reserved, This is an open access article under

the CC BY SA license (https://creativecommons.org/licenses/by-sa/4.0/) 
ISTIGHNA, Vol. 3, No 2, Juli 2020 P-ISSN 1979-2824 E-ISSN 2655-8459

Homepage: http://e-journal.stit-islamic-village.ac.id/index.php/istighna

Khoirun Nisa, Abdul Muhid

Peran Interaksi Sosial Terhadap Pola Asuh Perkembangan Anak

di Keluaraga Dalam Pandangan Islam

\section{A. PENDAHULUAN}

Lingkungan keluarga berfungsi sebagai landasan awal untuk membentuk kepribadian serta karakter manusia agar berkembang yang nantinya akan berdampak pada seorang individu itu sendiri dengan perlakuan baik ataupun buruk. Peran keluarga juga dapat membentuk perlakuan sikap kepribadian anak, serta dapat mengetahui proses pendidikan yang didapatkan anak, tidak hanya pada satu tempat yaitu pada lembaga pendidikan saja akan tetapi dari sumber manapun yang akan mengahasilkan yang namanya proses pembelajaran. ${ }^{1}$ oleh karena itu, Keluarga menjadi alih fungsi sebagai rumah yang dimana mempunyai banyak arti bukan hanya sebagai tempat berlindung juga menjadi sarana ketika ada suatau permasalahan dan menyediakan wadah untuk solusinya serta menjadi pegangan utama bagi anak dalam mencapai keberhasilan. Keluarga juga merupakan komunitas pertama bagi anak dalam interaksi. Interaksi antara orang tua dan anak berpengaruh terhadap pola asuh perkembangan anak.

Interaksi yang berlangsung dalam keluarga akan menentukan perlakuan anak terhadap orang lain dalam masyarakat. Sebagai contoh pada saat ini tidak sedikit orangtua yang sibuk dengan aktivitas baik dari pekerjaannya maupun menyibukkan diri. Anak juga mempunyai hak untuk diperhatikan sekedar ditanya apakah hari ini sangat menyenangkan ? itu pun sudah cukup, tetapi beda apa yang dilakukan orang tua saat ini mereka sibuk dengan beberapa aktivitas, mengakibatkan perhatian terhadap anak menjadi kurang dan kebanyakan orang tua menemukan solusi dari kesibukan mereka adalah contoh dengan memberikan sebuah gadget untuk menghiburnya, namun ada dampak dari penggunaan gadget tersebut. Meskipun berada dalam satu rumah, bapak, ibu dan anak sangat kurang dalam berkomunikasi karena masing-masing sibuk dengan gadgetnya dan aktivitas lainnya. Kesalahan interaksi dalam keluarga yang dikarenakan kurang optimalnya anggota keluarga dalam melaksanakan peran dan fungsinya masingmasing dapat menimbulkan berbagai permasalahan dalam keluarga.

Ketika perhatian orang tua dan interaksi anak kurang baik maka dampak yang terjadi sikap perilaku anak lebih cenderung anarkis, terutama dalam pergaulan bersosialisasi dengan masyarakat dan bahkan menjalin hubungan dengan keluarga. Melihat kondisi tersebut apabila dari pihak keluarga mendukung yang kurang kondusif dan sikap komuikasi yang kurang baik akan menjadi pemicu timbulnnya penyimpangan perilaku dan perbuatan-perbuatan negative

1 Wenny Hulukati and Wenny Hulukati, 'Peran Lingkungan Keluarga Terhadap Perkembangan Anak', Jurnal Musawa IAIN Palu, 7.2 (2015), 265-82. 
ISTIGHNA, Vol. 3, No 2, Juli 2020 P-ISSN 1979-2824 E-ISSN 2655-8459

Homepage: http://e-journal.stit-islamic-village.ac.id/index.php/istighna

Khoirun Nisa, Abdul Muhid

Peran Interaksi Sosial Terhadap Pola Asuh Perkembangan Anak

di Keluaraga Dalam Pandangan Islam

yang melanggar norma-norma di masyarakat, yang biasa disebut dengan kenakalan remaja. ${ }^{2}$

Berbicara tentang pola asuh, pola asuh yang diberikan oleh orang tua pada anak bisa dalam bentuk perlakuan fisik maupun psikis yang tercermin dalam tutur kata, sikap, perilaku dan tindakan dan dilakukan dengan sepenuh hati dan kasih sayang. Tugas orang tua berhak memilih cara memberikan pengasuhan yang dapat diterapkan dalam kehidupan keluarga. Pengasuhan akan berdampak kembali pada anak jika dilakukan dengan langkah baik maka hasil yang terlihat pada perkembangan anak akan baik, pun sebaliknya jika pengasuhan dilakukan dengan tidak baik atau sembarang tanpa kontrol maka akan berdampak tidak baik bagi setiap perkembangan anak. ${ }^{3}$

Penelitian yang dilakukan oleh Brian Abraham Rogi, menyimpulkan bahwa komunikasi antara orang tua dan anak adalah komunikasi yang dilakukan antar pribadi (interpersonal communication) dengan menggunakan pesan verbal yang mengandung perhatian,kasih sayang, empati dan dukungan dengan intensitas berkomunikasi . hal ini cukup berpengaruh terhadap perkembangan kepribadian anak serta berdampak pada kemungkinan terjadinya bentuk kenakalan remaja. ${ }^{4}$ Dalam hal ini pendapat diperkuat penelitian yang dilakukan Mohd Rafiq bahwa pola komunikasi dalam keluarga memiliki pengaruh kuat terhadapperkembangan jiwa dan hubungan sosial remaja karena sebagain besar kehidupannya ada didalam keluarga, situasi interaksi antara anggota keluarga, perlakuan anggota keluarga terhadap anaknya, memiliki pengaruh kuat terhadap kondisi psikis remaja ${ }^{5}$

Bentuk interaksi antara dua orang atau lebih akan berdampak kepada sifat masing-masing individu. Dalam hal ini dapat mempengaruhi sebuah perubahan dalam diri seseorang. Manusia lahir di dunia ini sebenarnya telah berinteraksi

2 'HUBUNGAN POLA KOMUNIKASI INTERPERNONAL DALAM KELUARGA DAN INTERAKSI SOSIAL TERHADAP KENAKALAN SISWA SMA SWASTA DI KOTA PADANGSIDIMPUAN | Rafiq | TAZKIR: Jurnal Penelitian Ilmu-Ilmu Sosial Dan Keislaman' <http://194.31.53.129/index.php/TZ/article/view/95> [accessed 6 June 2020].

3 'Pembelajaran Sebagai Proses Bimbingan Pribadi /Theo Riyanto | PERPUSTAKAAN UNIVERSITAS TERBUKA'<http://opac.ut.ac.id/detail-opac?id=16657> [accessed 6 June 2020].

4 Brian Abraham Rogi, 'PERANAN KOMUNIKASI KELUARGA DALAM MENANGGULANGI KENAKALAN REMAJA DI KELURAHAN TATAARAN 1 KECAMATAN TONDANO SELATAN', ACTA DIURNA KOMUNIKASI, $4.4 \quad$ (2015) $<$ https://ejournal.unsrat.ac.id/index.php/actadiurnakomunikasi/article/view/8657> [accessed 6 June 2020].

5 'HUBUNGAN POLA KOMUNIKASI INTERPERNONAL DALAM KELUARGA DAN INTERAKSI SOSIAL TERHADAP KENAKALAN SISWA SMA SWASTA DI KOTA PADANGSIDIMPUAN | Rafiq | TAZKIR: Jurnal Penelitian Ilmu-Ilmu Sosial Dan Keislaman'. 
ISTIGHNA, Vol. 3, No 2, Juli 2020 P-ISSN 1979-2824 E-ISSN 2655-8459

Homepage: http://e-journal.stit-islamic-village.ac.id/index.php/istighna

Khoirun Nisa, Abdul Muhid

Peran Interaksi Sosial Terhadap Pola Asuh Perkembangan Anak

di Keluaraga Dalam Pandangan Islam

dengan orang-orang disekitarnya termasuk lingkungan dimana dia berada, hal ini menjadi bukti konkret dari sebuah interaksi dengan individu lain. Interaksi sosial dalam hal ini dapat dilihat dari bagaimana cara dia berkomunikasi dari individu dengan individu lainnya, dan dalam hal ini juga interaksi sosial terlihat dari kehidupan kita sehari-hari termasuk pada diri kita sendiri, selain itu ada faktor lain yang mempengaruhi yaitu kemampuan dalam intelektual individu. ${ }^{6}$

Interaksi dalam kehidupan sehari-hari menimbulkan hubungan timbal balik antara individu. Interaksi dalam hal ini bertujuan untuk mempermudah proses sosialisasi antar indivisu untuk memenuhi kebutuhan dan kelangsungan hidupnya karena pada dasarnya manusia adalah makhluk sosial ${ }^{7}$ Dalam proses interaksi, pengalaman yang diperoleh anak terbentuk melalui interpretasi atas makna yang ditangkap selama proses interaksi.

Oleh karena itu, dari data data diatas penulis akan membahas peran interaksi sosial terhadap pola asuh perkembangan anak dalam keluarga. Lebih spesifik, akan membahas pentingnya bagaimana interaksi di dalam keluarga tersebut berlangsung dan pengaruhnya terhadap perkembangan pola asuh kepribadian anak dalam pandangan Islam

\section{B. METODE PENELITIAN}

Pada penelitian ini metode yang digunakan adalah kajian studi literatur. Untuk mengumpulkan data peneliti menggunakan beberapa database seperti pada neliti, moraref dan google scholar. Peneliti juga menggunakan beberapa kata kunci pencarian yaitu peran keluarga, pola asuh, perkembangan anak. Dari pencarian tersebut peneliti memilih dari beberapa data yang relevan yang sama dengan peneltian ini.

\section{HASIL DAN PEMBAHASAN}

Hasil yang dapat dijabarkan dari beberapa artikel yang terkait dengan peran interaksi sosial akan berpengaruh pada pola asuh anak di dalam keluarga merupakan hasil literature review. Hasil temuan pada proses literature review peran interaksi sosial terhadap pola asuh perkembangan anak diperlukan di dalam

\footnotetext{
${ }^{6}$ Febriani Fitriastuti, 'Pengaruh Interaksi Sosial dalam Keluarga dan Minat Belajar Siswa terhadap Prestasi Belajar Siswa', Oikonomia: Jurnal Pendidikan Ekonomi, 2.3 (2013), 27835.

7 Muhaammad Badrul Lail Siti Zubaidah, Syamsun Nahar, Pengaruh Pola Asih dan Interkasi sosial Terhadap Akhlak Siswa di Sekolah Menengah Pertama Islam Terpadu Nurul Azizi kota Medan, Edu Riligia: Vol. 1. No 4 Oktober- Desember 2017.
} 
ISTIGHNA, Vol. 3, No 2, Juli 2020 P-ISSN 1979-2824 E-ISSN 2655-8459

Homepage: http://e-journal.stit-islamic-village.ac.id/index.php/istighna

Khoirun Nisa, Abdul Muhid

Peran Interaksi Sosial Terhadap Pola Asuh Perkembangan Anak

di Keluaraga Dalam Pandangan Islam

sebuah keluarga berguna untuk mengetahui perkembangan anak maka dari itu diperlukannya sebuah interaksi yang baik antara orang tua dan anak.

\section{Peran Orang Tua Dalam Keluarga}

Orang tua adalah komponen keluarga yang terdiri dari ayah dan ibu, dan merupakan hasil dari sebuah ikatan perkawinan yang sah serta dapat membentuk sebuah keluaraga. Orang tua memiliki tanggung jawab untuk mendidik, mengasuh dan membimbing anak-anaknya untuk mencapai tahapan tertentu yang menghantarkan anak untuk siap dalam kehidupan bermasyarakat. Orang tua bertanggung jawab yang paling utama dalam perkembangan dan kemajuan anak. Menurut pandangan sosiologi, keluarga mempunyai arti luas meliputi semua pihak yang mempunyai hubungan darah atau keturunan, sedangkan dalam arti sempit keluarga meliputi orangtua dengan anak-anaknya. ${ }^{8}$

Ramayulis menjelaskan bahwa keluarga adalah sebagai unit pertama dan institusi pertama di dalam masyarakat dimana hubungan -hubungan yang terdapat di dalamnya sebagaian besar sifatnya hubungan langsung. Disitulah perkembangan individu dan awal mula terbentuknya tahap tahap perkembangan dan mulai interaksi dengannya, memperoleh pengetahuan, keterampilan, minat dan sikap dalam hidup. ${ }^{9}$

Anak mulai bisa mengenal dunia pendidikan dimulai dari kedua orang tua, dari masa dalam kandungan sampai ke tahap fase perkembangan selanjutnya. Orang tualah yang bertugas mendidik. Secara umum dalam hal inni baik psikomotor, kognitif maupun potensi afektif, dismaping itu orang tua juga harus memeihara jasmaniah muali dari memberi makan dan penghidupan yang layak. Dan semua itu merupakan beban dan tanggung jawab sepenuhnya yang harus dipikul oleh orang tua sesuai yang telah diamanahkan oleh Allah SWT.

Dalam mendidik anak, orang tua hendaknya memiliki ketentuan-ketentuan atau konsep untuk dapat mencapai tujuan yang diinginkan yaitu membentuk karakter dan kepribadian anak. Setiap orang tua pastilah memiliki ketentuan dan tujuan tertentu dalam mendidik anak. Ada beberapa konsep yang harus diperhatikan oeleh setiap orang tua (1) memberikan pendidikan tauhid kepada anak. Tauhid sendiri merupakan landasan islam yang paling penting dikenal oleh anak serta mengajarkan tauhid adalah sbuha kewajiban yang mutlak dan utama agar anak mengetahui batasan serta larangan dalam islam. (2) mengajarkan adab dan akhlak, tindakan yang perlu dan pentting untuk dilakukan serta diajarkan kepada anak, (3) bersikap adil terhadap semua anak karena salah satu hak anak

\footnotetext{
${ }^{8}$ Hendi Suhendi, Pengantar studi sosiologi keluarga (Pustaka Setia, 2001).

${ }^{9}$ RAMAYULIS, Pendidikan Islam Dalam Rumah Tangga (Jakarta: Kalam Mulia, 2001).
} 
ISTIGHNA, Vol. 3, No 2, Juli 2020 P-ISSN 1979-2824 E-ISSN 2655-8459

Homepage: http://e-journal.stit-islamic-village.ac.id/index.php/istighna

Khoirun Nisa, Abdul Muhid

Peran Interaksi Sosial Terhadap Pola Asuh Perkembangan Anak

di Keluaraga Dalam Pandangan Islam

adalah tidak mengistimewakan salah satu diantara mereka, (4) perhatikan perkembangan anak baik pada jasmani dan rohani, orang tua juga bertugas memenuhi kewajiban kebutuhan anak dan memperhatikan perkembangannya. Pada proses perkembangan anak peran orang tua harus selalu memperhatikan dan selalu konsisten. Serta dalam usaha pembinaan pembentukan karakter orang tua harus selalu mengawasi secara langsung agar bisa mengatahui bagaimana proses perkembangannya. ${ }^{10}$

Peran orang tua adalah segalanya dari tindakan yang diberikan dan akan berdampak kepada anak, termasuk dalam pembentukan karakter dan kepribadian anak. Dalam semua proses pembentukan pengetahuan, melalui berbagai pengasuhan yang dismpaikan oleh orang tua apalagi dilakukan oleh seorang ibu adalah sebagai pendidik pertama dan langkah awal. Peran orang tua dan keluarga menjadi peran sebagai pondasi dasar untuk memulai langakh pembudayaan karakter melalui pembiasaan bersikap dan berperilaku sesuai dengan karakter yang yang diharaokan orang tua. Pembiasaan yang dilakukan harus disertai dengan teladan dan diperkkuat dngan penanaman nilai-nilai budi pekeerti yang baik. ${ }^{11}$

\section{Interaksi Sosial Dalam Pandangan Islam}

Manusia sebagai individu yang tidak dapat dipisahkan dari kehidupan sosial Muhamamd Amin menjelaskan bahwa di dalam kehidupan bermasyarakat seseorang perlu berinteraksi dengan orang lain dari interaksi seseorang menemukan hakikat dirinya sebagai makhluk sosial yang saling membutuhkan. Dalam hal ini manusia dikatakan bisa bertahan hidup kalau manusia mampu berinteraksi antar sesama. Sebaliknya, manusia tidak akan mampu mempertahankan eksistensi hidupnya jika hanya seorang diri. menyadari bahwa betapa pentingnya hubungan antara individu dan masyrakat, Hossein Nasr mengatakan bahwa tidak ada masyarakat yang bisa eksis tanpa individu, dikatakan eksistensi baru adalah saat seorang individu membangun hubungan dengan individu-individu yang lain. ${ }^{12}$

${ }^{10}$ Azizah Maulina Erzad, 'PERAN ORANG TUA DALAM MENDIDIK ANAK SEJAK DINI DI LINGKUNGAN KELUARGA', ThufuLA: Jurnal Inovasi Pendidikan Guru Raudhatul Athfal, 5.2 (2018), 414 <https://doi.org/10.21043/thufula.v5i2.3483>.

${ }^{11}$ Hendarti Permono, 'Peran Orangtua Dalam Optimalisasi Tumbuh Kembang Anak Untuk Membangun Karakter Anak Usia Dini', 2013 <http://publikasiilmiah.ums.ac.id/handle/11617/3994> [accessed 7 June 2020].

12 'IMPLIKASI PRINSIP TASAMUH (TOLERANSI) DALAM INTERAKSI ANTAR UMAT BERAGAMA | Fikri: Jurnal Kajian Agama, Sosial Dan Budaya' <https://journal.iaimnumetrolampung.ac.id/index.php/jf/article/view/20> [accessed 6 June 2020]. 
ISTIGHNA, Vol. 3, No 2, Juli 2020 P-ISSN 1979-2824 E-ISSN 2655-8459

Homepage: http://e-journal.stit-islamic-village.ac.id/index.php/istighna

Khoirun Nisa, Abdul Muhid

Peran Interaksi Sosial Terhadap Pola Asuh Perkembangan Anak

di Keluaraga Dalam Pandangan Islam

Dalam mengembangkan masyarakat, islam sangat memperhatikan keseimbangan antara individu dan sosial. Salah satu bentuk keseimbangan tersebut adalah sebuah kedamaian. Satabilitas islam, dengan adanya normanormanya merupakan sebuah refleksi ide ide dan realisasi keseimbangan yang berkesinambungan. Nasr mengatakan bahwa ketidakseimbanagn dapat menyebabkan disentegrasi pada tingkat individu. Jadi, baik sebagai individu maupun sebagai komunitas sosial, manusia harus melakukan integrasi ( $\mathrm{Al}$ tauhid). ${ }^{13}$ Itulah sebabnya mengapa dalam suatu sistem kemasyarakatan memerlukan interaksi antar sesama.

Interaksi sosial pada prinsipnya merupakan cara terbaik untuk menyatukan masyarakat. Upaya integrasi tidak bertujuan untuk menjadikan umat manusia sebagai komunitas,tetapi menjalin hubungan untuk hidup saling menghargai perbedaan antar komunitas itu sendiri. Perbedaan sesungguhnya merupakan hal yang wajar terjadi tetapi bukan dalam bentuk pertikaian atau kerusuhan, sebaliknya berbentuk pengakuan terhadap keragaman atau pluralitas.

Azyumadi Azra mengatakan bahwa pluralitas pada prinsipnya justru dapat menciptakan kerukunan atara sesama manusia. Menurutnya pluralitas adalah suatu kodrati yang dimiliki oleh setiap manusia dan merupakan kepastian atau takdir dari Allah sebagaimana yang diisyratkan dalam kitab suci. Semua perbedaan menurutnya harus mendorong untuk saling mengenal dan menumbuhkan apresiasi dan saling peduli satu sama lain. ${ }^{14}$

Dalam pola interaksi sosial, terdapat tiga model atau pola interaksi. (1) pola interaksi konsentris dimana Hossein Nasr mengatakan bahwa suatu interaksi harus berangkat dari kesadaran akan keberadaan Tuhan karena pada suatu hubungan harus terpusat pada tuhan. Hubungan dengan Tuhan bisa dengan cara membangun interaksi dengan sesame anggota keluarga, masyarakat tempat tinggal, masyarakat bangsa dan yang terakhir bersatu dengan komunitas Islam. Pola interaksi ini seperti gambaran diatas, membawa pemahaman bahwa jika ada hubungan seorang individu dengan Tuhan baik, maka dapat dipastikan individu tersebut memiliki hubungan yang baik dengna sesama. Begitupun sebaliknya. (2) pola interaksi timbal balik, pola yang dimaksud adalah untuk melakukan interaksi antar individu dan sesama masyarakat. Hubungan interaksi timbal balik juga dapat dilakukan pada individu dan masyarakat yang seagama dan yang berbeda agama. Interaksi sosial juga harus mampu mempertemukan individu, suku, bangsa,dan

${ }^{13}$ Uki Sukiman, 'RESEPSI SASTRA NOVEL SARAH KARYA 'ABBAS MAHMUD AL-'AQQAD', Adabiyyāt: Jurnal Bahasa dan Sastra, $12.1 \quad$ (2013), 208-28 <https://doi.org/10.14421/ajbs.2013.12110>.

14 Siti Maftuhah, 'Dialog Antar Umat Beragama' <https://www.academia.edu/5367600/Dialog_Antar_Umat_Beragama> [accessed 6 June 2020]. 
ISTIGHNA, Vol. 3, No 2, Juli 2020 P-ISSN 1979-2824 E-ISSN 2655-8459

Homepage: http://e-journal.stit-islamic-village.ac.id/index.php/istighna

Khoirun Nisa, Abdul Muhid

Peran Interaksi Sosial Terhadap Pola Asuh Perkembangan Anak

di Keluaraga Dalam Pandangan Islam

masyarakat yang berebda karena pada dasarnya manusia diciptakan untuk saling berinteraksi (3) pola interaksi terikat, pola ini didasarkan pada kesepakatan atau perjanjian. Menurut Hossein Nasr pola ini cenderung digunakan untuk masyarakat, budaya, dan bangsa yang berada dalam komunitas yang tidak seragam atau berbeda. Ketiga pola tersebut interaksi hendaknya disatukan karena ketiganya memiliki arti fungsi yang berbeda sehingga bisa saling melengkapi dan digunakan secara terpadu dan terintegrasi untuk mewujudkan interaksi yang berkualitas. Semua bentuk interaksi yang dilakukan manusia pada prinsipnya bertujuan untuk menciptakan kehidupan yang teratur, rukun, dan bersatu. Di dalam islam bertujuan menciptakan masyarakat kasih sayang, masyarakat yang didasarkan bukan pada kompetisi dan ego individual, tetapi melainkan didasarkan pada kelembutan dan kesadaran hidup yang saling membutuhkan. ${ }^{15}$

\section{Pola Asuh Perkembangan Anak Dalam Islam}

Pola Asuh dalam Islam merupakan pembahasan yang sudah ditetapkan di dalam ajaran Islam. Di dalamnya dijelaskan bahwa mendidik dan membimbing anak merupakan suatu kewajiban bagi setiap orang muslim karena seorang anak merupakan suatu kewajiban yang harus dijaga dan dipertanggungjawabkan oleh orang tua. Hal ini dilandasakan dalam firma Allah SWT Q.s At-Tahrim Ayat 6 :

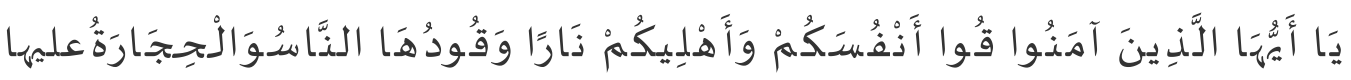

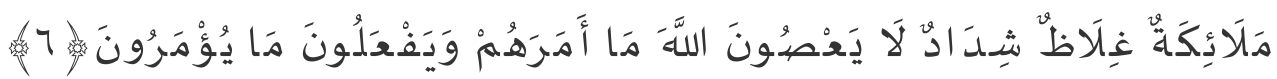

Yang artinya "Hai orang-orang yang beriman, peliharalah dirimu dan keluargamu dari api neraka yang bahan bakarnya adalah manusia dan batu, penjaganya malaikat-malaikat yang kasar, keras, dan tidak mendurhakai Allah terhadap apa yang diperintahkan-Nya kepada mereka dan selalu mengerjakan apa yang diperintahkan"

Maksud dari ayat diatas perintah memelihara keluarga termasuk anak, dan bagaimana orang tua bisa mengarahkan ke yang lebih baik, serta mendidik dan mengajarkan anak agar terhindar dari siksa pedih api neraka. Hal ini juga memberikan arahan cara bagaimana orangtua harus mampu menerapkan pendidikan yang bisa membuat anak mempunyai prinsip untuk menjalankan hidupnya dengan positif, serta menjalankan ajaran islam dengan benar, sehingga mampu membentuk mereka menjadi aak yang mempunyak akhlak yang baik dan memberikan sesuatu yang bisa bermanfaat.

${ }^{15}$ Mursyid Mursyid, 'Pluralitas Agama Dan Faham Keagamaan: Pelajaran Dari Pondok Pesantren Nurul Jadid', AT-TURAS: Jurnal Studi Keislaman, 4.1 (2017), 80-96 $<$ https://doi.org/10.33650/at-turas.v4i1.201>. 
ISTIGHNA, Vol. 3, No 2, Juli 2020 P-ISSN 1979-2824 E-ISSN 2655-8459

Homepage: http://e-journal.stit-islamic-village.ac.id/index.php/istighna

Khoirun Nisa, Abdul Muhid

Peran Interaksi Sosial Terhadap Pola Asuh Perkembangan Anak

di Keluaraga Dalam Pandangan Islam

Pola asuh pada konsep islam tidak menjelaskan lebih spesifik bagaimana model pola auh yang terbaik atau yang lebih baik, tetapi lebih mejelaskan tentang segala hal yang sepatutunya dilakukan oleh setipa orang tua yang semuanya itu tergantung pada dilihat dari situasi dan kondisi masing-masing anak. Oleh karena itu, betapa pentingnya semua hal yang dilakukan oleh orang tua dan akan berpengaruh terhadap pada pembentukan kepribadian anak. Terutama pada anak yang mengalami masa perkembangan seperti mencontoh setiap perilaku yang ada pada sekitarnya. ${ }^{16}$

Konsep pola asuh dalam islam lebih berorientasi pada cara praktik pengasuhan bukan pada model pola asuh dalam sebuah keluaraga ${ }^{17}$ Nashih Ulwan mendeskripsikan tentang pengasuhan lebih mengarah kepada metode pendidikan yang dapat berpengaruh terhadap anak. (1) pola asuh yang bersifat keteladanan, dengan cara melakukan hal baik yang dilakukn oleh orang tua , tugas anak adalah meneladani serta meniru apa yang telah dilakukan oleh orangtua. (2) pola asuh yang bersifat nasihat, adapun didalamnya berupa ajakan yang kepada anak dengan sikap yang lembut dan menyenangkan, bisa juga dengan memberikan stimulus melalui teknik cerita yang disertai perumapamaan mengandung pelajaran dan nasihat. (3) pola asuh dengan perhatian, sebagai hak anak adalah memperoleh perhatian serta pengawasan oleh orang tuanya dalam hal ini pada pendidikan sosialnya, pendidikan spirirtual, moral dan konsep pendidikan serta dalam praktik pembelajaran. Bisa diterapkan teknik dengan memberikan nilai imbalan (reward) dan hukuman (punishment) kepada anak. Agar anak tersebut lebih menghragai waktu dan pekerjaan yang sedang dan telah dilakukan, Nasih Ulwan menambhakna pendapat bahwa konsep pola asuh dalam pandangan islam lebih berorientasi pada praktik pengasuhan, ada beberapa unsur yang berpengaruh dalam pendidikan moral islam dalam lingkup keluarga, hal ini berkaitan dengan praktik pengasuhan orangtua terhadap anak mereka. Mahfuzh menjelaskan ada beberapa unsur yang harus dilaksanakan oleh orang tua terkait dengan pendidikan moral islam. (1) menanamkan akidah kepada anak, (2) latihan beribadah, dalam hal ini tugas orangtua memberikan pengajaran dini tentang perihal ibadah agar anak mengenal siapa Tuhannya sejak dini (3) persahabatan orang tua terhadap anak, diantara mereka harus mempunyai rasa saling mengasihi, meyanyangi dan

${ }^{16}$ Rabiatul Adawiah, 'Pola Asuh Orang Tua dan Implikasinya terhadap Pendidikan Anak: Studi pada Masyarakat Dayak di Kecamatan Halong Kabupaten Balangan', Jurnal Pendidikan Kewarganegaraan, 7.1 (2017), 33-48 <https://doi.org/10.20527/kewarganegaraan.v7i1.3534>.

17 Psycho Islamic Smart Parenting - Oleh: Muallifah <http://www.bukabuku.com/browses/product/9789799637123/psycho-islamic-smartparenting.html> [accessed 6 June 2020]. 
ISTIGHNA, Vol. 3, No 2, Juli 2020 P-ISSN 1979-2824 E-ISSN 2655-8459

Homepage: http://e-journal.stit-islamic-village.ac.id/index.php/istighna

Khoirun Nisa, Abdul Muhid

Peran Interaksi Sosial Terhadap Pola Asuh Perkembangan Anak

di Keluaraga Dalam Pandangan Islam

saling melindungi, tugas orang tua adalah memberi rasa nyaman agar anak tidak merasa jauh dari kasih sayang orang tua. ${ }^{18}$

\section{Keterkaitan Antara Interaksi Sosial Terhadap Pola Asuh Perkembangan Anak Dalam Pandangan Islam}

Sebuah interaksi termasuk dalam lingkup psikologi dan dikatakan hal yang sangat penting dalam kehidupan dimana pun dan kapan pun, termasuk dalam lingkungan keluarga. Interaksi terbentuk dengan baik dan harmonis dalam seubuah keluarga adalah menjadi damban setiap orang Pembentukan interaksi yang baik dan harmonis dalam keluarga menjadi dambaan setiap orang. Peranan keluarga terutama orang tua, menjadi peran penting bagi pembentukan karakter seorang anak, terlebih lagi bila anak tersebut mulai memasuki masa remaja. Keluarga juga merupakan tempat dimana proses interaksi sosial berlangsung dan menjadi tempat ditanamkannya pendidikan moral dan agama. Sehingga keluraga terutama orang tua harus ikut bertanggung jawab dalam membimbing anaknya. Orang tua menjadi sumber utama informasi serta pengawasan dan pembinaan terhadap generasi muda yang nantinya akan melanjutkan cita-cita bangsa. Interaksi efektif mampu menjadi jalan bagi ornag tua untuk memantau dan membimbing anaknya.namun terkadang Kebanyakan orang tua saat ini cenderung sibuk mengurusi pekerjaan sehingga pendidikan anak teracuhkan dan interaksi komunikasi sehari hari antara orang tua dan anak juga tidak akan terjalin dengan

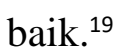

Dalam pandangan psikologi pola asuh perkembangan anak merupakan rentang kehidupan masa yang paling mendasar dalam membentuk fase selanjutnya, Hurlock menjelaskan bahwa anak menjadi tanggung jawab orang tua, baik yang masih dalam kandungan, masa bayi hingga anak mencapai usia dewasa dan mandiri, serta pengasuhan orang tua berfungsi untuk memberikan kelekatan dan ikatan emosioanal atau kasih sayang antara orang tua dan anaknya dan sebagai penerimaan dan tuntunan dari orang tua bagaimana orang tua menerapakan kedisiplinan. ${ }^{20}$ Ada beberapa gaya atau model menurut Baumrid ada empat gaya pengasuhan keluarga terhadap anak (1) ototitarian, atau biasa disebut otoriter. Yaitu sebagai perlakuan yang membatasi dan mendesak anak untuk

18 Nurussakinah Daulay, 'POLA ASUH ORANGTUA DALAM PERSPEKTIF $\begin{array}{llllll}\text { PSIKOLOGI DAN } & \text { ISLAM', } & \text { Darul } & \text { Ilmi, } & 2.2 & \text { (2014) }\end{array}$ <http://194.31.53.129/index.php/DI/article/view/417> [accessed 6 June 2020].

${ }^{19}$ Meni Handayani, 'PERAN KOMUNIKASI ANTARPRIBADI DALAM KELUARGA UNTUK MENUMBUHKAN KARAKTER ANAK USIA DINI', Jurnal Ilmiah Visi, 11.1 (2016), 57-64 <https://doi.org/10.21009/JIV.1101.8>.

${ }^{20}$ Elizabeth B. Hurlock, Perkembangan Anak Jilid 1 (Erlangga AAA909090976543, 1978). 
ISTIGHNA, Vol. 3, No 2, Juli 2020 P-ISSN 1979-2824 E-ISSN 2655-8459

Homepage: http://e-journal.stit-islamic-village.ac.id/index.php/istighna

Khoirun Nisa, Abdul Muhid

Peran Interaksi Sosial Terhadap Pola Asuh Perkembangan Anak

di Keluaraga Dalam Pandangan Islam

mengikuti arahan mereka. Orang tua yang otoriter akan menerapkan batas kendali yang tegas pada anak. Dampak anak dari orang tua yang otoriter sering kali tidak bahagia, ketakutan, minder ketika membandingkan diri dengan orang lain, tidak mampu memulai aktivitas dan memiliki kemampuan komunikasi yang lemah dan mungkin akan berprilaku agresif. (2) otoritatif , berfungsi mendorong anak untuk berprilaku mandiri namun masih menerapkan batas dan kendali pada tindakan mereka. Tindakan yang dilakukan orang tua bersifat hangat dan penyayang trhadap anak. Serta menunjukkan kesenangan dan dukungan sebagai respon terhadap perilaku kontruktif pada anak. Orang tua juga berharap perilaku anak menjadi dewasa dan mandiri dan sesuai dengan tingkatan usianya. Anak yang dalam didikan orang tua otoritatof cenderung sering kali ceria, bisa mengendalikan diri dan mandiri serta berorientasi pada prestasi. (3) Pola Asuh Uninvolved adalah tindakan dimana yag dilakukan orang tua bersikap mengabaikan dan lebih mengutamakan kebutuhan dan keinginan orang tua daripada kebutuhan dan keinginan anak, tidak adanya tuntutan,laranagan ataupun komunikasi terbuka anatar orang tua dan anak. (4) pola asuh Permissive, tindakan orangtua yang terlalu membebaskan anak dalam segala hal tanpa adanya tuntutan dan anak dibolehkan untuk melakukan apa saja yang diinginkannya. Dari beberapa gaya dapat diambil kesimpulan bahwa setiap orang berhak menentuka pola asuh yang akan diterapkan kepad anaknya dan bisa mengobinasikan dengan berbagai tipe yang ada serta melihat situasi dan kondisi anak serta menyesuaikannya.$^{21}$

Dalam pandangan Islam sebuah interaksi terhadap sesama itu menjadi sangat penting kita saling membutuhkan antar sesama. Segala eberagaman yang terjadi membawa kita untuk melakukan interaksi sosial terhadap umat masyarakat dan menjadi suatu kodrati yang dimiliki oleh setiap manusia seperti yang ada pada al-Qur'an bahwa semua perbedaan menurutnya harus mendorong untuk saling mengenal dan menumbuhkan apresiasi dan saling peduli satu sama lain.

Dari sudut padang Islam bahwa pola asuh perkembangan anak sudah sangat jelas ditetapkan dalam islam bahwa mendidik anak adalah suatu kewajiban tugas orang tua. Perilaku dan sikap yang dilakukan anak adalah tergantung dari didikan orang tuaya, maka dalam islam menganjurkan orang tua dalam mendidik dengan cara baik serta penuh kasih sayang.

\footnotetext{
21 Nurussakinah Daulay, 'POLA ASUH ORANGTUA DALAM PERSPEKTIF PSIKOLOGI DAN ISLAM', Darul Ilmi, $2.2 \quad$ (2014) <http://194.31.53.129/index.php/DI/article/view/417> [accessed 6 June 2020].
} 
ISTIGHNA, Vol. 3, No 2, Juli 2020 P-ISSN 1979-2824 E-ISSN 2655-8459

Homepage: http://e-journal.stit-islamic-village.ac.id/index.php/istighna

Khoirun Nisa, Abdul Muhid

Peran Interaksi Sosial Terhadap Pola Asuh Perkembangan Anak

di Keluaraga Dalam Pandangan Islam

\section{KESIMPULAN}

Keluarga memiliki peranan yang sangat besar terhadap perkembangan pola asuh kepribadian anak, melalui sebuah Interaksi yang dilakukan dalam keluarga maka akan terjalin hubungan baik saling mengerti dengan suatu keadaan. Interaksi juga membawa dampak baik kepada anak dan orang tua. Dilihat dari segi pandangan islam interaksi menjadi hal yang sangat dianjurkan untuk dilakukan karena dengan kita berinteraksi kita bisa mencipatakan sebuah tindakan seperti kita saling betegur sapa, saling peduli kepada sesama. Dengan berinteraksi Islam bertujuan menciptakan masyarakat yang penuh kasih sayang, masyarakt yang didasarka buka hanya pada kompetisi dan memetingkan ego individual semata, tetapi melainkan didasarkan pada kelembutan dan kesadaran hidup yang saling membutuhkan antar sesama. Selanjutnya jika pola asuh perkembangan anak dalam pandnagan islam sudah sangat jelas jika dalam islam sangat menganjurkan untuk tugas orang tua mendidik anak dengan baik dalam keluaraga seperti yang tercantum dalam surat at-Tahrim ayat 6. perintah memelihara keluarga termasuk anak, dan bagaimana orang tua bisa mengarahkan ke yang lebih baik, serta mendidik dan mengajarkan anak agar terhindar dari siksa pedih api neraka.

\section{REFERENSI}

Adawiah, Rabiatul, 'Pola Asuh Orang Tua dan Implikasinya terhadap Pendidikan Anak: Studi pada Masyarakat Dayak di Kecamatan Halong Kabupaten Balangan', Jurnal Pendidikan Kewarganegaraan, $7.1 \quad$ (2017), 33-48 <https://doi.org/10.20527/kewarganegaraan.v7i1.3534>

Daulay, Nurussakinah, 'POLA ASUH ORANGTUA DALAM PERSPEKTIF PSIKOLOGI DAN ISLAM', Darul Ilmi, $2.2 \quad$ (2014) <http://194.31.53.129/index.php/DI/article/view/417> [accessed 6 June 2020]

—, 'POLA ASUH ORANGTUA DALAM PERSPEKTIF PSIKOLOGI DAN ISLAM', Darul Ilmi, $2.2 \quad$ (2014) <http://194.31.53.129/index.php/DI/article/view/417> [accessed 6 June 2020]

Erzad, Azizah Maulina, 'PERAN ORANG TUA DALAM MENDIDIK ANAK SEJAK DINI DI LINGKUNGAN KELUARGA', ThufuLA: Jurnal Inovasi $\begin{array}{lllll}\text { Pendidikan Guru Raudhatul Athfal, } 5.2 & \text { (2018), } 414\end{array}$ <https://doi.org/10.21043/thufula.v5i2.3483>

Fitriastuti, Febriani, 'Pengaruh Interaksi Sosial dalam Keluarga dan Minat Belajar Siswa terhadap Prestasi Belajar Siswa', Oikonomia: Jurnal Pendidikan Ekonomi, 2.3 (2013), 27835 
ISTIGHNA, Vol. 3, No 2, Juli 2020 P-ISSN 1979-2824 E-ISSN 2655-8459

Homepage: http://e-journal.stit-islamic-village.ac.id/index.php/istighna

Khoirun Nisa, Abdul Muhid

Peran Interaksi Sosial Terhadap Pola Asuh Perkembangan Anak di Keluaraga Dalam Pandangan Islam

Handayani, Meni, 'PERAN KOMUNIKASI ANTARPRIBADI DALAM KELUARGA UNTUK MENUMBUHKAN KARAKTER ANAK USIA DINI', Jurnal Ilmiah Visi, 11.1 (2016), 57-64 <https://doi.org/10.21009/JIV.1101.8>

'HUBUNGAN POLA KOMUNIKASI INTERPERNONAL DALAM KELUARGA DAN INTERAKSI SOSIAL TERHADAP KENAKALAN SISWA SMA SWASTA DI KOTA PADANGSIDIMPUAN | Rafiq | TAZKIR: Jurnal Penelitian Ilmu-Ilmu Sosial Keislaman' <http://194.31.53.129/index.php/TZ/article/view/95> [accessed 6 June 2020]

Hulukati, Wenny, and Wenny Hulukati, 'Peran Lingkungan Keluarga Terhadap Perkembangan Anak', Jurnal Musawa IAIN Palu, 7.2 (2015), 265-82

Hurlock, Elizabeth B., Perkembangan Anak Jilid 1 (Erlangga AAA909090976543, 1978)

'IMPLIKASI PRINSIP TASAMUH (TOLERANSI) DALAM INTERAKSI ANTAR UMAT BERAGAMA | Fikri : Jurnal Kajian Agama, Sosial Dan Budaya' <https://journal.iaimnumetrolampung.ac.id/index.php/jf/article/view/20> [accessed 6 June 2020]

Maftuhah, Siti, 'Dialog Antar Umat Beragama' <https://www.academia.edu/5367600/Dialog_Antar_Umat_Beragama> [accessed 6 June 2020]

Mursyid, Mursyid, 'Pluralitas Agama Dan Faham Keagamaan: Pelajaran Dari Pondok Pesantren Nurul Jadid', AT-TURAS: Jurnal Studi Keislaman, 4.1 (2017), 80-96 <https://doi.org/10.33650/at-turas.v4i1.201>

Permono, Hendarti, 'Peran Orangtua Dalam Optimalisasi Tumbuh Kembang Anak Untuk Membangun Karakter Anak Usia Dini', 2013 <http://publikasiilmiah.ums.ac.id/handle/11617/3994> [accessed 7 June 2020]

Psycho Islamic Smart Parenting - Oleh: Muallifah <http://www.bukabuku.com/browses/product/9789799637123/psycho-islamicsmart-parenting.html> [accessed 6 June 2020]

RAMAYULIS, Pendidikan Islam Dalam Rumah Tangga (Jakarta: Kalam Mulia, 2001)

Rogi, Brian Abraham, 'PERANAN KOMUNIKASI KELUARGA DALAM MENANGGULANGI KENAKALAN REMAJA DI KELURAHAN TATAARAN 1 KECAMATAN TONDANO SELATAN', ACTA DIURNA KOMUNIKASI, $\quad 4.4 \quad$ (2015) <https://ejournal.unsrat.ac.id/index.php/actadiurnakomunikasi/article/view/8657> [accessed 6 June 2020]

Suhendi, Hendi, Pengantar studi sosiologi keluarga (Pustaka Setia, 2001)

Sukiman, Uki, 'RESEPSI SASTRA NOVEL SARAH KARYA 'ABBAS MAHMUD AL-'AQQAD', Adabiyyāt: Jurnal Bahasa dan Sastra, 12.1 (2013), 208-28 <https://doi.org/10.14421/ajbs.2013.12110> 